\title{
Genesis and Death of Vocal Control Neurons During Sexual Differentiation in the Zebra Finch
}

\author{
John R. Kirn and Timothy J. DeVoogd \\ Department of Psychology, Cornell University, Ithaca, New York 14853
}

Several song-related regions in the adult zebra finch brain have substantially more neurons in males than in females. Such differences appear to arise from sex differences in circulating steroids during early posthatch life. In the present study, developmental mechanisms involved in the production of sex differences are explored by examinations of the normal time course of posthatch neurogenesis and cell death in vocal control circuits. As a first step toward determining whether rates of neuron production may be different in males and females, tritiated thymidine, a marker of cell division, was administered to zebra finches at various times during the first month after hatching. Birds were sacrificed at $60 \mathrm{~d}$. The number of cells formed after hatching and present at $60 \mathrm{~d}$ was then evaluated in 3 vocal control regions-HVc (hyperstriatum ventralis pars caudalis) and its 2 principal targets, RA (robust nucleus of the archistriatum) and Area $X$. Cell death was quantified by counts of normal and pyknotic, degenerating cells made in these nuclei in additional, untreated birds of both sexes at $5 \mathrm{~d}$ intervals from 5 to $45 \mathrm{~d}$ of age.

The combined results of these experiments suggest that differential cell death is a major factor in the development of sex differences in the song control system and provide the first direct evidence for sex differences in cell death in the developing telencephalon. Although developmental time tables differ among the 3 brain areas examined, at specific ages significantly higher numbers of pyknotic cells were observed in HVc, RA, and presumptive Area $X$ in females compared to males. Peak levels of cell death in RA occur 4-6 weeks after hatching. This is about 3 weeks after the onset of sex differences in steroid levels that, in turn, lead to differential organization of song system nuclei. This pattern of results suggests that designation for death and actual cell loss are temporally dissociated in this system.

Neuron proliferation for HVC and Area X, but not RA, continues throughout the first $\mathbf{3 0} \mathrm{d}$ after hatching, and a significant sex difference was found in the number of cells present in $\mathrm{HVC}$ at $\mathbf{6 0} \mathrm{d}$ that were formed after hatching. Comparisons

\footnotetext{
Received Oct. 26, 1988; revised Jan. 27, 1989; accepted Jan. 31, 1989.

We wish to thank Dr. Barbara Finlay for the use of laboratory facilities, technical assistance, and helpful comments on the manuscript, and Dr. Elizabeth Regan for supplying some of the birds. This work was submitted by the first author to partially fulfill the requirements of the Ph.D. at Cornell University. The research was supported by NIH HD 21033 to T.DV.

Correspondence should be addressed to Dr. John Kirn at his present address: Box 137, Rockefeller University, 1230 York Avenue, New York, NY 10021. Copyright (C) 1989 Society for Neuroscience 0270-6474/89/093176-12\$02.00/0
}

of the timing of cell death and cell incorporation suggest that this difference may be best accounted for by differential survival of neurons formed after hatching rather than differential rates of neuron production.

Neither differential neurogenesis nor differential neuron death can fully account for the apparent extreme sexual dimorphism in the number of neurons in Area $X$. We suggest that sex differences in Area $X$ may involve sex-specific patterns of differentiation for similar numbers of neurons. Such differential specification in males and females could result in Area $X$ being apparent in mature males but not in mature females. Thus, the results suggest that complementary mechanisms operate during the development of sex differences in gross morphology among multiple, anatomically and functionally interconnected brain areas.

Neuron incorporation and death continue into the second month after hatching in male zebra finches. Much of song learning occurs during the second month. The contiguity between song acquisition and elaboration of song system structures suggests that factors such as the recruitment of new neurons and their survival/death should be considered as possible mediators of functional change.

Sex differences in neuron number have been documented within specialized regions of all major divisions of the CNS in a variety of vertebrates (reviewed in Arnold and Gorski, 1984; Arnold and Breedlove, 1985; DeVoogd, 1986; Kelley, 1988). Adult sexual dimorphisms are believed to result from the presence of sex differences in circulating steroids during development. For many of these systems, the sex differences are reduced or erased if hormone levels in early life are experimentally altered in one sex to approximate those characteristic of the other sex. How might these cffects on ncuron number arise? In principle, hormone effects on adult neuron number could be mediated by 3 sorts of processes: hormonal modulation of neurogenesis, of cell survival, or of the specification of cell type (see Arnold and Gorski, 1984).

The present study investigates the development of dimorphic structures in the avian song system. This system is comprised of several discrete, interconnected brain nuclei (Nottebohm et al., 1976; for reviews see Konishi, 1985; DeVoogd, 1986). The vocal control system provides an especially intriguing model in which to study the formation of neural sex differences, as the sex differences occur in multiple interconnected brain areas that have staggered developmental timetables, and which therefore may use different mechanisms in the creation of the dimorphisms. The 3 largest nuclei in the song system are the hyperstriatum ventralis pars caudalis $(\mathrm{HVc})$ in the telencephalon and 
its 2 principal targets, the robust nucleus of the archistriatum (RA) and Area X in the lobus parolfactorius (Nottebohm et al., 1976). In adult zebra finches, the volumes of $\mathrm{HVc}$ and $\mathrm{RA}$ are several times larger in males than in females (Nottebohm and Arnold, 1976), primarily a result of these nuclei having many more neurons in males than in females (Gurney, 1981; Konishi and Akutagawa, 1985; Nordeen et al., 1987). Area $X$ is the largest nucleus in the male song system. This nucleus is also the most dimorphic in the zebra finch song system - it cannot be distinguished in adult females (Nottebohm and Arnold, 1976; Ryan and Arnold, 1981). Sex differences in neuroanatomy are associated with sex differences in behavior: male zebra finches sing, normal females do not (Immelmann, 1969; Gurney, 1982).

In the zebra finch song system, as in many other dimorphic neural systems, the presence or absence of gonadal stcroids carly in development initiates the formation of neural dimorphisms. Adult female zebra finches that were exposed to testosterone (T) or estradiol (E2) soon after hatching have song control nuclei that are more male-like than nuclei in untreated females (Gurney, 1981, 1982; Nordeen et al., 1987). HVc and RA are much larger and have many more neurons in these treated birds than in normal females and Area $X$ can readily be distinguished. Moreover, when the early hormone treatment is followed by adult $\mathrm{T}$ treatments, females begin to sing (Gurney, 1982; PohlApel and Sossinka, 1984).

The early development of HVc and RA is similar in male and female zebra finches (Bottjer et al., 1985; Konishi and Akutagawa, 1985). HVc then becomes dimorphic in the third week after hatching as the number of neurons found in the nucleus in males increases while the number in females quickly reaches a plateau (Nordeen and Nordeen, 1988b). In RA, dimorphisms develop as cell size, dendritic field volume and cell spacing increase in males (Konishi and Akutagawa, 1985; DeVoogd et al., 1986), while the number of neurons, the dendritic field volume and the apparent size of the nucleus decrease in females (Bottjer et al., 1985; Konishi and Akutagawa, 1985; DeVoogd et al., 1986).

Area $\mathrm{X}$ has never been identified in female zebra finches. In males, it can first be seen at about $12 \mathrm{~d}$ after hatching and has reached most of its adult size by about day 25 (Bottjer et al., 1985). Area $X$ is especially interesting because, in contrast to $\mathrm{HVc}$ and RA, none of its neurons appear to concentrate androgens and few if any concentrate estrogens (Arnold et al., 1976; Arnold, 1980; Gahr et al., 1987; Walters et al., 1988). Thus, while steroids may act directly on HVc, their effects on Area X are likely to be indirect.

The present research was designed to better understand factors contributing to the development of dimorphisms in the song system. The time course of neurogenesis over the first $30 \mathrm{~d}$ after hatching was determined for $\mathrm{HVc}_{\mathrm{c}}, \mathrm{RA}$, and Area $\mathrm{X}$ in male and female zebra finches using ${ }^{3} \mathrm{H}$-thymidine and a long survival time. This was to show whether neurogenesis overlaps with differentiation in these brain regions, and whether development in males and females involves differential incorporation of neurons produced in the first month after hatching. In a second experiment, the incidence of both normal and pyknotic, degenerating cells was measured in each of these brain regions in order to evaluate the role of cell death in the formation of brain dimorphisms. The combined results of the 2 experiments shed light on the developmental mechanisms operating in the sexual differentiation of a complex neural circuit controlling a learned behavior.

\section{Materials and Methods}

Neurogenesis: animal treatment and histology. A total of 20 male and female zebra finches obtained from our breeding colony received 3 subcutaneous injections of ${ }^{3} \mathrm{H}$-thymidine $(2.5 \mu \mathrm{Ci} / \mathrm{gm}$ body weight; specific activity, $20 \mathrm{Ci} / \mathrm{mm}$; New England Nuclear). These were given 48 $\mathrm{hr}$ apart during one of the following intervals: posthatch days 2-6, 8$12,14-18,20-24$, or $26-30$, thereby labeling cells undergoing mitosis during these intervals. Each injection group consisted of 2 males and 2 females. All injections were administered between 3:30 and 5:00 p.m. to control for possible circadian rhythms in the length of the cell mitotic cycle. At 60 d of age (range, 59-62), subjects were deeply anesthetized and perfused intracardially with $0.9 \%$ saline followed by fixation in $20 \%$ isopropyl alcohol, 4\% paraformaldehyde (Perfix, Fisher). Brains were embedded in paraffin and sectioned coronally at $10 \mu \mathrm{m}$ on a rotary microtome. Sections were processed for conventional autoradiography (slides were dipped in Kodak NBT-2 photographic emulsion, exposed at $4^{\circ} \mathrm{C}$ for 3-8 weeks, and developed in Kodak D-19). Sections were then stained with cresylecht violet, dehydrated, and coverslipped from xylene.

Neurogenesis: data collection. RA and HVc were analyzed for labeled neurons unilaterally at $750 \times$ magnification in 3 equally spaced sections, one each from the rostral, middle, and caudal portions of the nuclei. Neurons were distinguished from glia based on cell size and staining characteristics. Cells with a large, pale nucleus, 1-2 distinct nucleoli and a darkly staining cytoplasm were counted as neurons. Neurons were classified as being labeled if the number of silver grains over the nucleus was at least 10 times background density (Fig. 1). In all 3 brain regions, many small, lightly stained cells were labeled that were not counted as they are probably not neurons (Fig. $1 D$ ). With the aid of an ocular microscope grid, neuron density in HVc, Area X, and RA was estimated by counting the number of neurons present in $20-100 \%$ of the crosssectional area of the nucleus within each of the 3 sections measured and dividing by the area sampled. (The reduced sampling area was possible as neuron densities based on samples of $20 \%$ of the cross-sectional area of a nucleus did not differ by more than $11 \%$ from densities derived from larger samples.) The unit of count for neurons was based on cell nuclei. Density measures were corrected for the overestimation that would be caused by nuclei split between tissue sections using the correction formula of Abercrombie (1946). The borders of the song-related nuclei were traced using the projection microscope in sections spaced $120 \mu \mathrm{m}$ apart. The total volume of a nucleus was determined with the aid of a computerized digitizing tablet and was multiplied by neuron density to yield an estimate of total neuron number.

It is not possible to compare males and females on the number of neurons in Area $X$ because this nucleus is not differentiated in adult females. Therefore, a method was devised to compare the frequencies of labeled neurons in Area $X$ in males to the analogous region in females. The position of Area X in male dorsolateral LPO was first reconstructed, and this information was used to find and sample the geometrically equivalent brain region in females. Three sections were chosen for this inferential analysis in males and females. The sections were equally spaced between the most rostral section containing LPO and the most rostral section containing ectostriatum, landmarks chosen because they are unambiguous, reliably encompass Area $X$ in males and occupy positions near Area $X$, thus reducing reconstruction errors that might result from variation in the plane of sectioning. Arbitrary boundaries encompassing Area X in dorsolateral LPO of males were created from microprojector tracings in the following manner (Fig. 2). A line parallel to the ventricular zone and at $20 \%$ of the total distance from the ventricular zone to the lateral extent of LPO subdivided LPO into medial and lateral components. A second line perpendicular to the first and at $30 \%$ of the distance from the ventral surface of the section to the dorsal extreme of LPO further subdivided LPO into dorsal and ventral components. The dorsolateral quadrant of LPO (DL-LPO), as delineated with this procedure, reliably encompassed Area $\mathrm{X}$ in males. This procedure was repeated in females, providing an equivalent site at which to compare the sexes on neuron incorporation. With this method, density of labeled cells (expressed as labeled cells/1000 cells) was obtained in both sexes. For all analyses, slides were coded so that the experimenter was blind to the sex and age of the subjects.

Cell death: histology. At $5 \mathrm{~d}$ intervals $( \pm 1.5 \mathrm{~d})$ covering posthatch days 5-45 (hatch day = day 1), 3 zebra finches of each sex (54 birds total) were anesthetized and perfused with $0.9 \%$ saline followed by Perfix. Following overnight storage in fixative, brains were dehydrated 

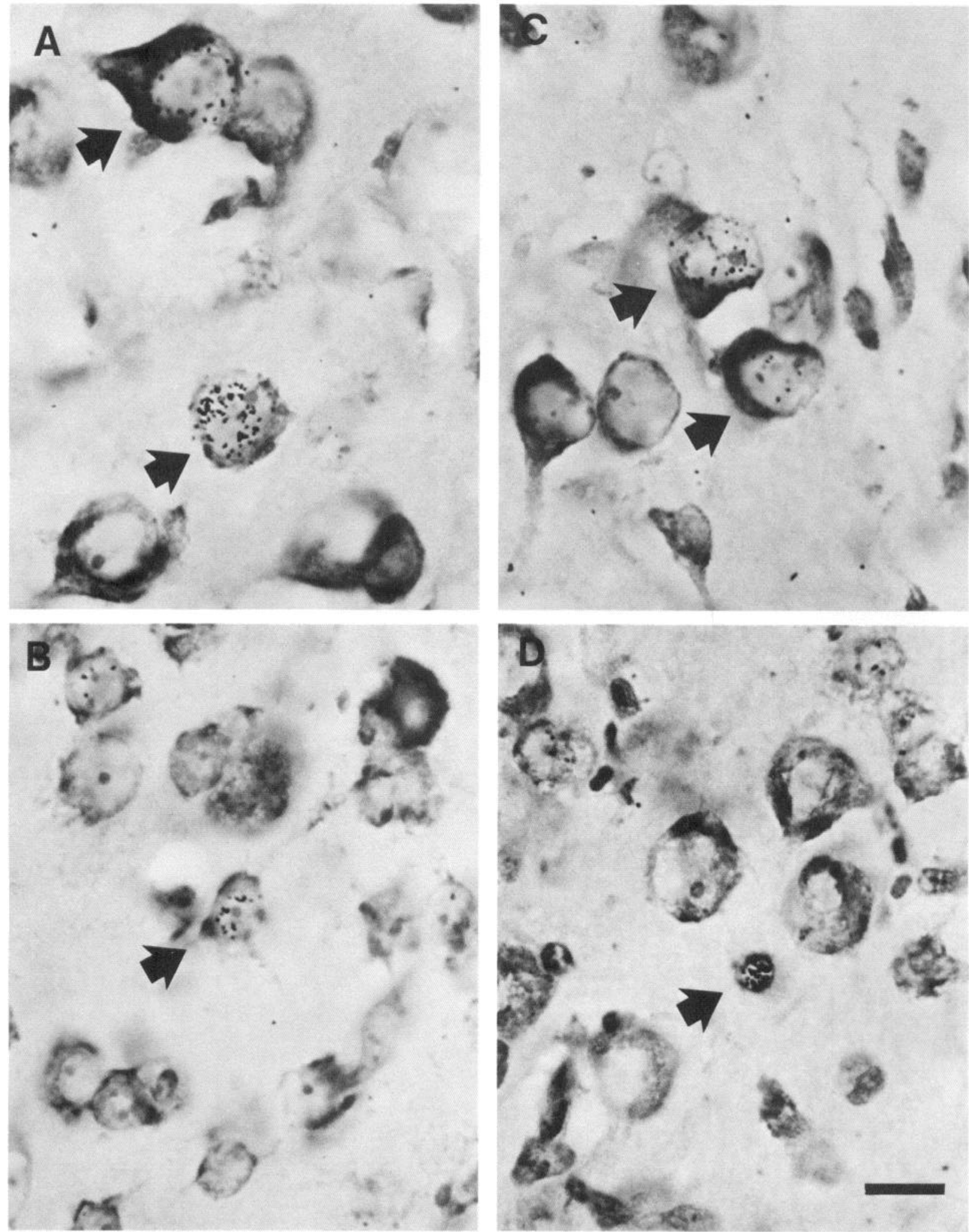

Figure 1. Photomicrographs of representative labeled neurons in $\mathrm{HVc}(A)$, Area $\mathrm{X}(B)$, and $\mathrm{RA}(C)$, of males following posthatch tritium injections. Relatively few labeled cells with clear neuronal morphology were found in RA after posthatch ${ }^{3} \mathrm{H}$ injections. $(D)$, Example of labeled non-neural cells in RA. Scale bar, $10 \mu \mathrm{m}$.

and embedded in paraffin. Ten micron coronal sections were cut on a rotary microtome and stained with cresylecht violet.

Cell death: data collection. Neuron densities in HVc, DL-LPO, and RA were calculated in $20-100 \%$ of the nucleus cross-sectional area in
3 equally spaced sections, one each from the rostral, middle, and caudal portions of the brain region at $750 \times$ as described for measures of ${ }^{3} \mathrm{H}$ labeled cells. At $80 \mu \mathrm{m}$ intervals, the area of HVc and RA was determined with the aid of a computerized digitizing tablet and multiplied 
by the sampling interval to estimate nucleus volume. Measures of neuron density were then multiplied by total nucleus volume to derive estimates of total neuron number.

Pyknotic, degenerating cells can be identified by their shrunken, darkly staining, liquified appearance (Chu-Wang and Oppenheim, 1978; Wong and Hughes, 1987). Each brain region in cross-section was completely scanned for pyknotic cells in 5-6 cqually spaced tissue scetions. Examples of typical degenerating cells in HVc are illustrated in Figures 3, $A, B$. Generally, pyknosis obscures cellular phenotype. However, cells that appeared to be in early stages of degeneration often had features characteristic of neurons (Fig. 3, $C, D$ ). Tissue was deliberately stained lightly in order to be able to resolve intracellular detail when using high magnification and illumination. Under these conditions, it was possible to discriminate reliably between pyknotic cells (in which intracellular structure is breaking down) and other darkly staining profiles such as blood cells. Often multiple pyknotic fragments in close proximity were found (Fig. $3 B$ ). Unless separated by at least one cell diameter, these fragments were counted together as one degenerating cell. Although these precautions may underestimate the actual number of degenerating cells, they provide a standardized method for uncovering relative sex and age differences in cell death.

Indices of cell death were calculated in 2 ways for $\mathrm{HVc}$ and RA. Estimates of total pyknotic cell number were derived by multiplying the number of pyknotic cell profiles per area sampled by total nucleus volume. The amount of cell death was also calculated as a function of the number of normal neurons present (pyknotic cell/1000 neurons). Although these 2 measures often covary, they provide different sorts of information (see Finlay et al., 1986, for a more detailed appraisal of different methods for quantifying cell death). Counts of total pyknotic cells can reveal the developmental time course of cell death and can serve as a relative index of the total number of cells dying at a particular age. Cell death ratios provide an index of the proportion of cells that are dying at a particular age. Each method has advantages and disadvantages. Pyknotic cell ratios are a more sensitive measure of cell death than are estimates of total pyknotic cell number (Wong and Hughes, 1987). However, pyknotic cell ratios suffer the criticism that they may change during development as a result of changes in the denominator (normal cell number), as well as in the numerator (pyknotic cell number), of the ratio. Apparent increases in cell death ratios over time might, in fact, reflect cell "loss" associated with factors other than death, such as the dedifferentiation or emigration of normal cells.

Area X per se can be delineated and analyzed only in males. As in the neurogenesis experiment, the sexes were compared by analyzing a dorsolateral zone in lobus parolfactorius (DL-LPO) that was defined in the same way for males and females and that included Area X in males. This region was scanned completely in cross-section for pyknotic cells in 5-6 equally spaced tissue sections from males and females between $5 \mathrm{~d}$ of age (considerably before the age at which $X$ can be distinguished in males) and $30 \mathrm{~d}$ of age (the age by which Area $X$ has an adult shape and appearance in males). Pyknotic cell counts in DL-LPO were expressed as cell death ratios (pyknotic cells/1000 neurons). Cell death ratios were also calculated for medial LPO. This region is interposed between DL-LPO and the ventricular zone where cells destined for DLLPO are created (Tsai et al., 1981b). This measure, therefore, provides a first indication of whether differential death occurs among cells that may be migrating toward Area $\mathrm{X}$ from the ventricular zone. For all analyses, the experimenter was unaware of the age and sex of the subjects.

Statistical analyses. For descriptive purposes data have been presented in the form of means + SE. Two-way analysis of variance has been used to compare sexes and ages. Previous work suggests that sexual differentiation of song nuclei occurs during much of the first month after hatching (Gurney, 1981; Pohl-Apel and Sossinka, 1984; Nordeen et al., 1987). Thus, the present experiment was designed to evaluate development of song system nuclei across multiple ages, with relatively few animals used in each age group. With this design, statistically powerful comparisons can be made of main effects related to sex and of overall trends across multiple ages but not between specific ages.

\section{Results}

Posthatch neurogenesis

Neurogenesis values must be interpreted carefully as labeled neurons were counted in birds killed a month or more after the last ${ }^{3} \mathrm{H}$-thymidine injection. Thus, differences between injection

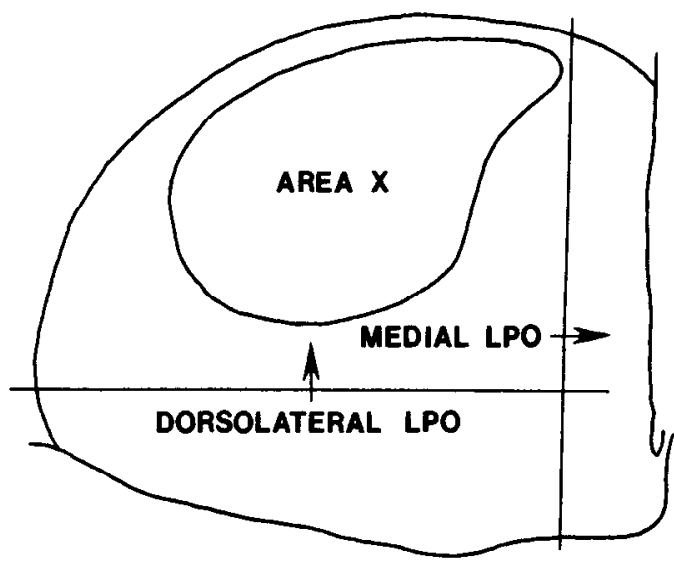

Figure 2. Schematic representation of the way in which LPO was subdivided in order to measure the frequency of labeled neurons in comparable regions of the brain in males (where Area $X$ is clearly delineated) and in females (where Area $\mathrm{X}$ cannot be resolved).

groups or between males and females could be caused by differential migration or cell death during the intervening time, as well as by differences in neurogenesis. These values, therefore, can be used to demonstrate the existence of neurogenesis but not its absolute magnitude.

About $2 \%$ of the neurons in HVc at $60 \mathrm{~d}$ of age are labeled in males by thymidine injections given at different intervals during the first $30 \mathrm{~d}$. This number does not differ significantly with age [Fig. $4 A ; F(4,10)=0.677, p>0.10$ ]. There are substantial sex differences in the total number of labeled neurons found in HVc at $60 \mathrm{~d}$ of age $[F(1,10)=19.605, p<0.001]$. This is seen for each of the injection groups (Fig. $4 A$ ), resulting on average in males having 6 times as many labeled cells as females.

Averaging across all thymidine injection groups, about $4 \%$ of the neurons in DL-LPO are labeled in males. As in $\mathrm{HVc}$, the number of cells labeled does not differ with age [Fig. $4 B ; F(4,10)$ $=0.947, p>0.10]$. In contrast to HVc, this labeling does not appear to differ between sexes. Although about 1.3 times as many labeled neurons occur across all injection groups in males as in females $(41 \pm 4.6$ labeled cells $/ 1000$ in males and $32 \pm$ $4.0 / 1000$ in females), this does not result either in a significant overall sex difference $[F(1,10)=2.460 ; p>0.10]$ or in a significant sex $\times$ age interaction $[F(4,10)=2.069, p>0.10]$.

In RA, the number of cells labeled differs with age, in contrast to HVc or presumptive Area X [Fig. $4 C ; F(4,10)=7.939, p<$ $0.005]$. This occurs as far more labeled neurons are found in RA after thymidine injections during days 2-6 than during the later ages $[182 \pm 11$ for days $2-6$ vs. $27 \pm 9$ for days $8-30$; $F(1,10)=29.236, p<0.001]$. In RA, as in HVc, there are large sex differences in labeling [overall sex effect: $F(1,10)=5.402$, $p<0.05$ ]. The largest sex difference occurs following ${ }^{3} \mathrm{H}$-thymidine injections on days 2-6 when the number of labeled neurons found is relatively high in both sexes. Males also have more labeled neurons after ${ }^{3} \mathrm{H}$-thymidine injections at later ages. Across all injection groups, males have 3 times as many labeled neurons as females ( $59 \pm 21$ for males vs $20 \pm 14$ for females).

\section{Neuron number and cell death in $\mathrm{HVC}$}

Large changes occur over early development in the number of neurons in HVc (Fig. $5 A$ ). Boundaries of HVc could first be reliably distinguished at 10 days after hatching. At this time, 

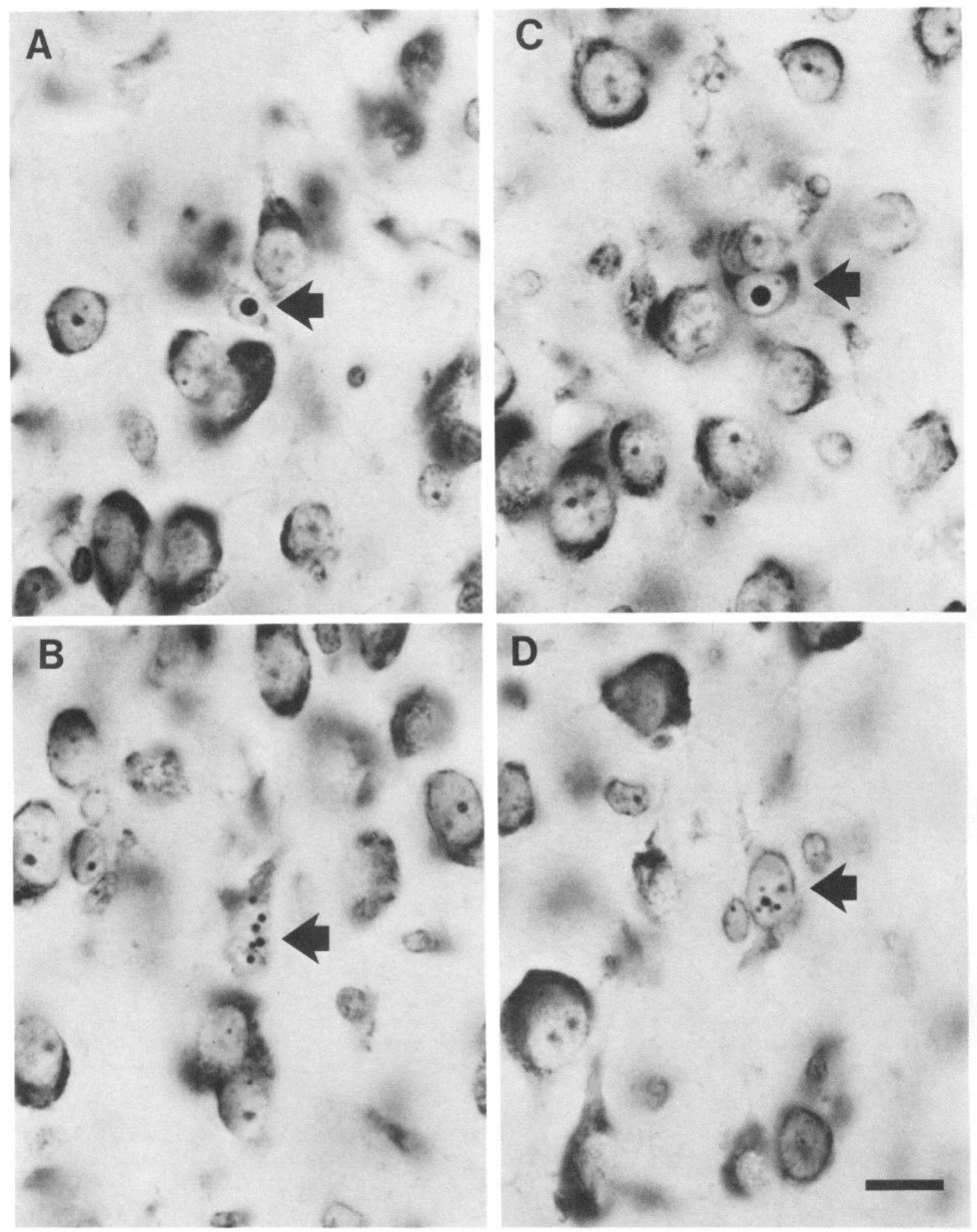

Figure 3. Photomicrographs of degenerating cell profiles in $\mathrm{HVc}$ of a 20-d-old female (arrow). The prior identity of pyknotic cells was usually obscured $(A, B)$. However, in some, cases, cells were observed that appeared to be undergoing early stages of degeneration and that showed characteristics of neuronal morphology $(C, D)$. Scale bar, $10 \mu \mathrm{m}$.

the number of neurons in $\mathrm{HVc}$ is similar in males and females. Thereafter, neuron number diverges substantially between the sexes [age by sex interaction: $F(8,46)=6.37, p<0.001$ ]. By 60 days of age (values for these were obtained from the neurogenesis animals), there is more than an 8 -fold difference between the sexes in the number of neurons in HVc.

Pyknotic cells occur in $\mathrm{HVc}$ at all ages studied (Fig. 5, B, C). Estimates of total pyknotic cells (Fig. $5 B$ ) are quite variable, but 
A.
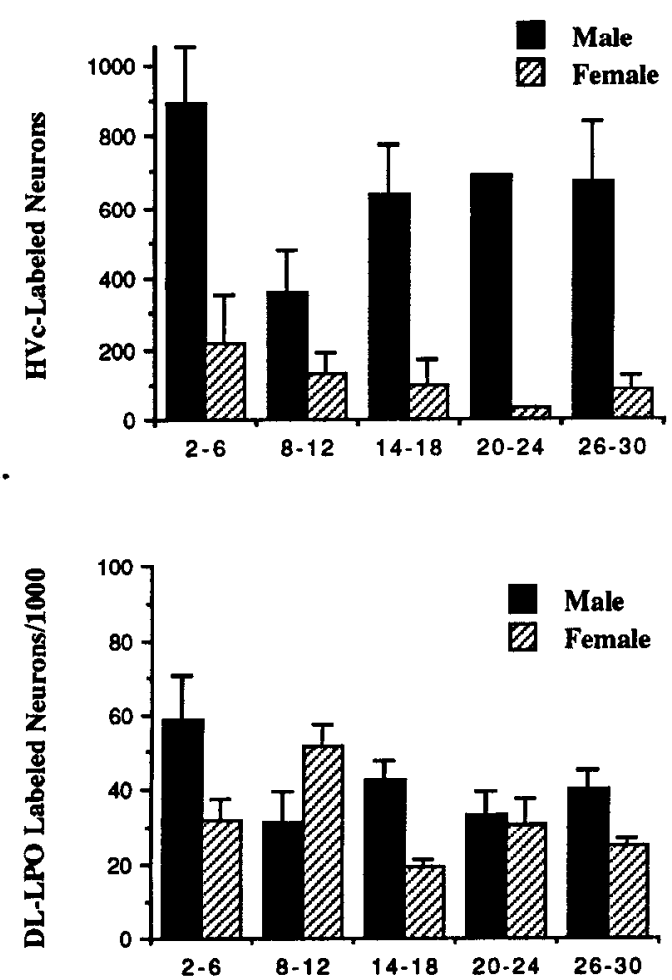

B.

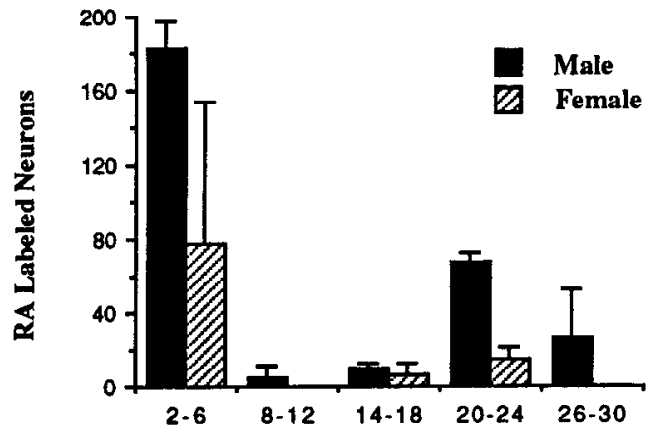

C.

Injection age

Figure 4. Total number of labeled neurons $( \pm \mathrm{SE})$ in HVc $(A)$, DLLPO $(B)$, and RA $(C)$ in males and females at $60 \mathrm{~d}$ after hatching, following $3{ }^{3} \mathrm{H}$-thymidine injections covering one of the following age intervals: days $2-6,8-12,14-18,20-24$, or $26-30$ after hatching.

tend to be somewhat higher for females than males at 15 and 20 days of age. However, there is neither a significant overall sex difference $[F(1,32)=2.45 ; p>0.10]$ nor a significant sex $x$ age interaction $[F(7,32)=0.99 ; p>0.25]$ in the total number of degenerating cells observed. For days 15 and 20 , the period during which the largest loss of neurons is observed in females, sex differences in the number of pyknotic cells approach statistical significance $[F(1,8)=3.91 ; p=0.08]$.

In contrast, there are clear sex differences present in the proportion of cells in $\mathrm{HVc}$ that are dying [Fig. $5 C$; sex effect: $F(1,32)$ $=22.94, p<0.0005$ ]. There are also differences in the ratio of pyknotic cells per 1000 normal cells across the ages measured [age effect: $F(7,32)=3.31, p<0.01]$. Closer examination of the data reveals that these differences are focused: the sex difference is largest at 20,25 , and $30 \mathrm{~d}$ of age $[F(1,32)=31.28 ; p$
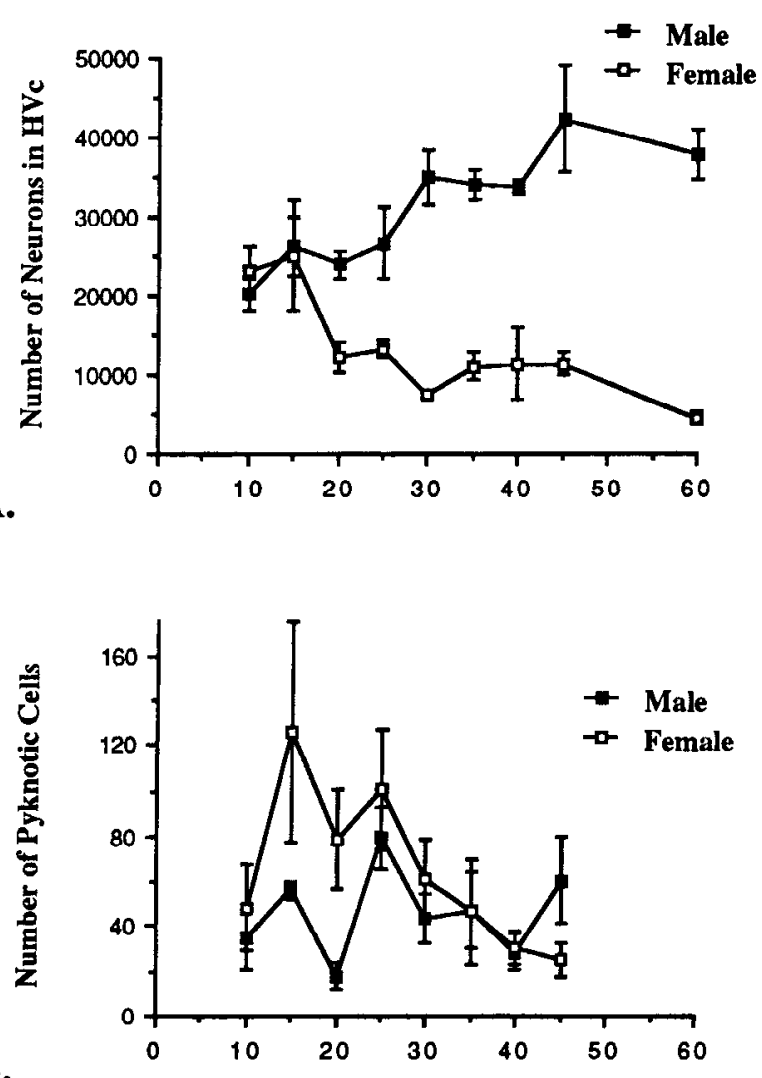

B.

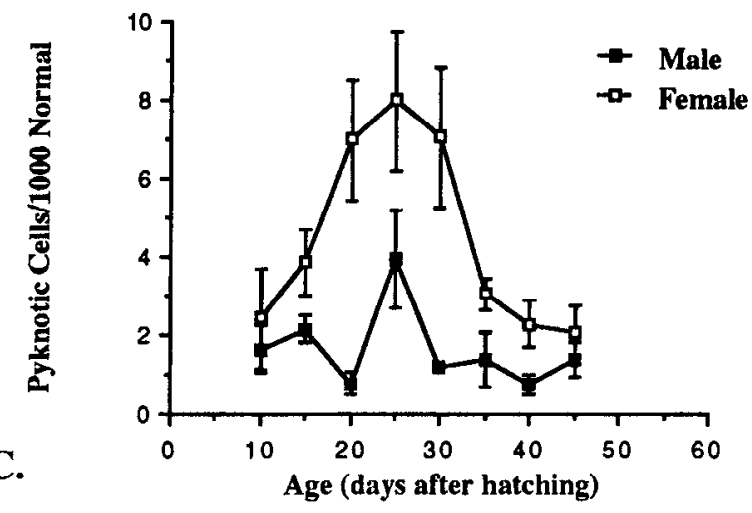

Figure 5. Developmental changes in HVc of males and females (mean $\pm \mathrm{SE}$ ) in the total number of neurons $(A)$, the total number of pyknotic cells $(B)$, and the ratio of pyknotic cells per 1000 neurons in HVc $(C)$.

$<0.0005$ ] and is much smaller at $10,15,35,40$, and $45 \mathrm{~d}$ of age $[F(1,32)=2.98,0.05<p<0.1]$.

\section{Neuron number and cell death in Area X/DL-LPO}

Cell death ratios for males and females in DL-LPO, the region that includes Area $\mathrm{X}$ in males (Fig. 6A), are very low relative to values obtained for $\mathrm{HVc}$ and RA (Figs. $5 C$ and $7 C$, respectively). However, here too, more pyknotic cells per 1000 neurons are found in DL-LPO in females than in males $[F(1,24)=6.65$, $p<0.02]$. The proportion of pyknotic cells found varies with age $[F(5,24)=4.94, p<0.005]$. The sex difference is greatest in 15-, 20-, and 25-d-old animals, which are also the ages at which the incidence of pyknotic cells is greatest in both sexes. 


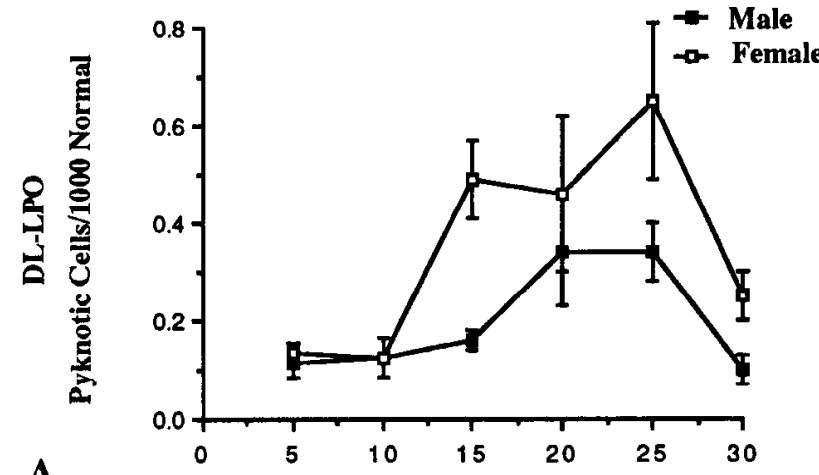

A.
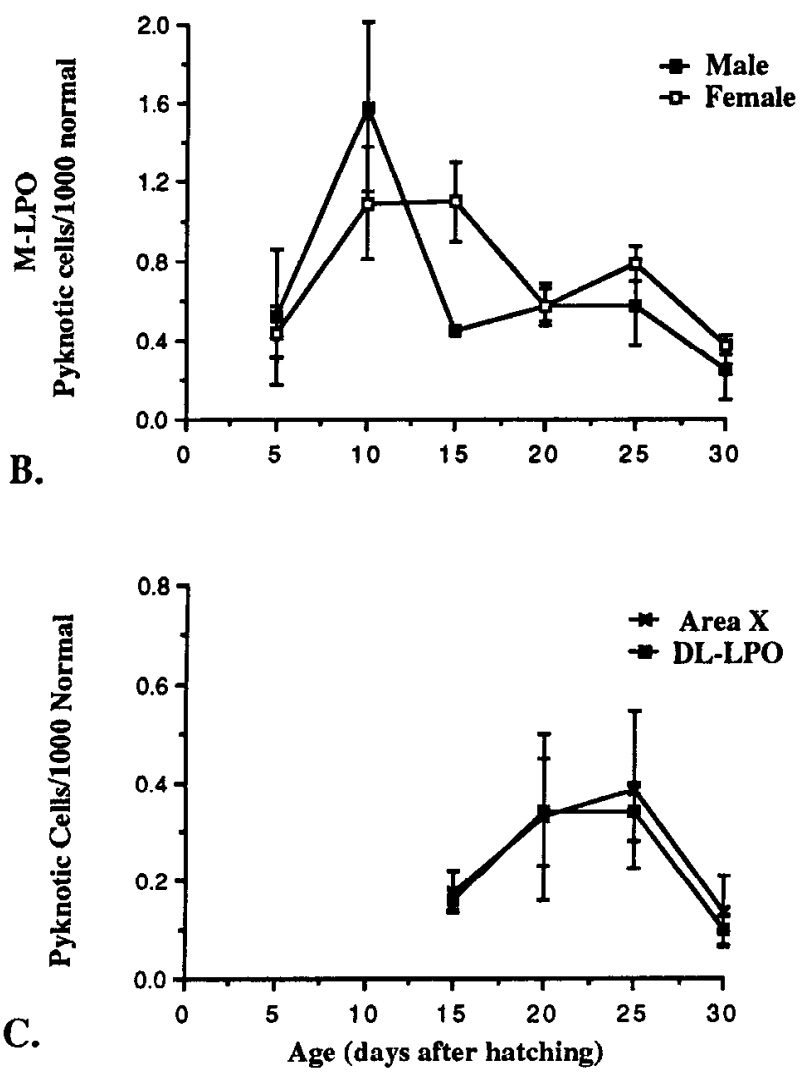

Figure 6. Developmental changes in subdivisions of LPO in the ratio of pyknotic cells per 1000 normal cells (mean $\pm S E$ ) in males and females between 5 and $30 \mathrm{~d}$ of age. $A$, Dorsolateral LPO (DL-LPO), the region that in males includes Area X. $B$, Medial LPO, the region through which the neurons that comprise Area $\mathrm{X}$ must migrate. $C$, In males, pyknotic cell ratios in DL-LPO correspond closely to values obtained specifically in Area $X$.

The overall time course and magnitude of cell death in M-LPO (Fig. 6B), the region medial to Area $\mathrm{X}$, is different from that found in DL-LPO. Peak cell death ratios in M-LPO in both sexes occur about $10 \mathrm{~d}$ earlier than in DL-LPO and are approximately double the ratios observed in DI -I.PO. Moreover, in M-LPO, there are no significant sex differences in pyknotic cell ratios $[F(1,24)=0.32, p>0.25$ for sex; $F(5,24)=1.48, p$ $>0.20$ for sex $\times$ age].

In order to determine whether values for DL-LPO provide a reasonable estimate of death in Area $\mathrm{X}$, comparisons were also made in males between cell death in DL-LPO generally and cell

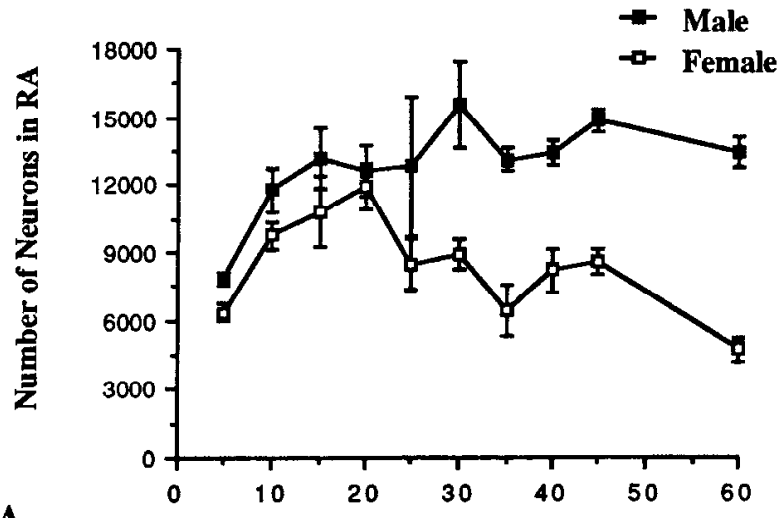

A.
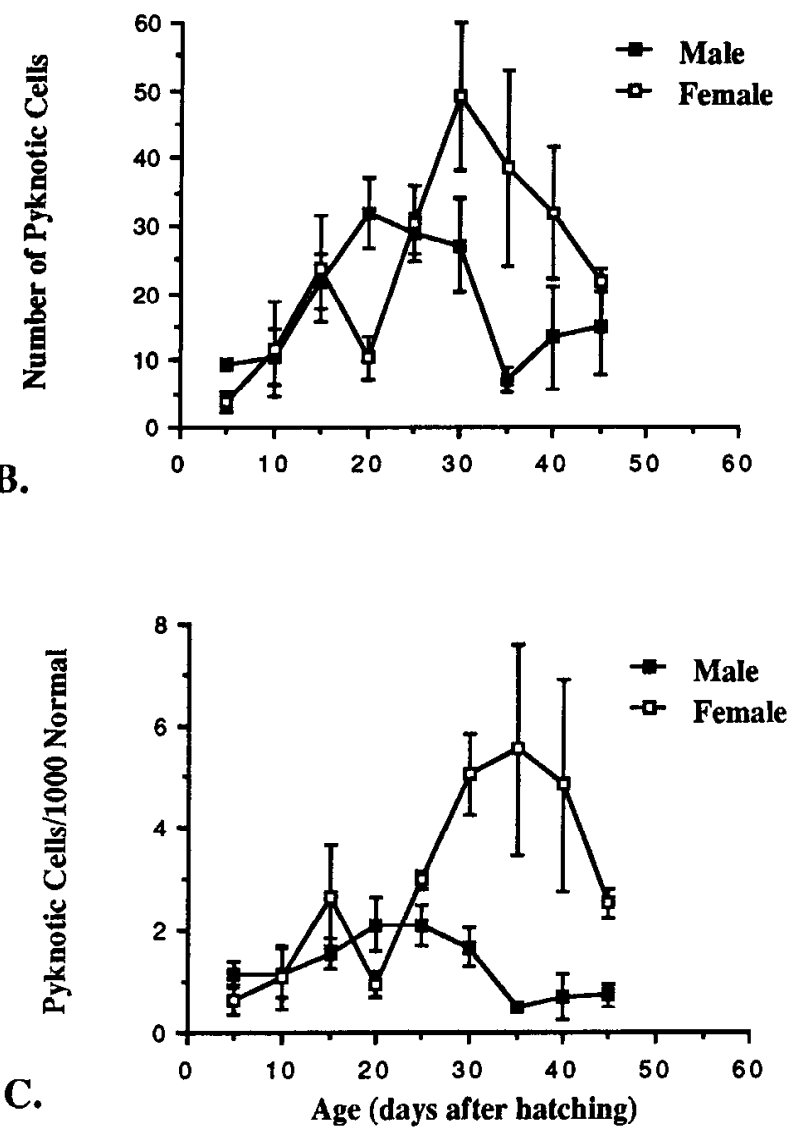

Figure 7. Developmental changes in RA of males and females (mean $\pm \mathrm{SE}$ ) in the total number of neurons $(A)$, the total number of pyknotic cells $(B)$, and the ratio of pyknotic cells per 1000 normal cells $(C)$.

death in Area $X$ specifically (Fig. 6C). From $15 \mathrm{~d}$ of age (the earliest age at which the boundaries of Area $X$ could be clearly delineated in males) through $30 \mathrm{~d}$ of age, there is close agreement in pyknotic cell ratios in the 2 regions. These results suggest that in males, degenerating cell ratios in dorsolateral LPO accurately reflect cell death ratios in Area X. More importantly, these results suggest that the augmented cell death found in DL-LPO of females represents the death of presumptive Area X cells.

\section{Neuron number and cell death in $R A$}

RA can be clearly delineated from surrounding brain areas at $5 \mathrm{~d}$ of age. In both sexes, the number of neurons in RA increases 
until about $20 \mathrm{~d}$ after hatching (Fig. $7 A$ ), at which time the sexes have similar numbers of neurons. Thereafter, the number of neurons in males remains relatively stable. In contrast, the number of neurons in females decreases by $61 \%$ from day 20 to day 60 . This decrease results in a significant interaction between sex and age $[F(9,54)=2.95, p<0.01]$ as well as an overall sex difference in neuron number $[F(1,54)=57.25, p<0.0001]$.

The total number of pyknotic cells observed in RA is similar in males and females through $25 \mathrm{~d}$ of age (Fig. $7 B$ ). However, females 30,35 , and 40-d-old tend to have higher numbers of degenerating cells than males [sex $\times$ age interaction: $F(8,36)=$ $1.90, p<0.10]$.

When these data are expressed in the form of pyknotic cells per 1000 neurons, females have substantially greater cell death than males at 30, 35, 40, and $45 \mathrm{~d}$ of age (Fig. 7C). This results in significant overall sex differences in cell death, as well as a significant age $\times$ sex interaction $[F(1,36)=11.62, p<0.002$; $F(8,36)=2.29, p<0.05$, respectively].

\section{Discussion}

Neurogenesis after hatching

The first experiment examined the contribution made to $\mathrm{HVc}$, $\mathrm{RA}$, and Area $\mathrm{X}$ in 60 -d-old zebra finches by neurogenesis during the first month after hatching. During this time, these regions become dimorphic in size and in the number of neurons they contain. The results indicate that neurogenesis of precursor cells destined for song control nuclei $\mathrm{HVc}, \mathrm{RA}$, and Area $\mathrm{X}$ continues beyond hatching in the zebra finch. Neurons destined for $\mathrm{HVc}$ and Area $X$ continue to be produced throughout the first $30 \mathrm{~d}$. Neurogenesis in adults has been reported in HVc of canaries (Goldman and Nottcbohm, 1983) and zebra finches (Nottebohm, 1985). Since significant numbers of labeled cells were found in $\mathrm{HVc}$ and Area $\mathrm{X}$ after ${ }^{3} \mathrm{H}$-thymidine injections made as late as 26-30 days of age (the oldest injection group examined in the present study), it is possible that these nuclei incorporate new cells continually throughout life. In contrast, few labeled neurons were found in RA, and most of these were observed after ${ }^{3} \mathrm{H}$-injections restricted to days $2-6$. This finding suggests that most of the proliferation of neurons destined for RA ends soon after hatching.

In the chicken embryo, neurogenesis in the archistriatum is completed prior to neurogenesis in the lobus parolfactorius and neostriatum (Tsai et al., 1981a). The present data suggest that the rules governing the temporal order of neurogenesis for $\mathrm{HVc}$ (now known to be located in the neostriatum), RA, and Area $\mathrm{X}$ are similar to those dictating the overall order of genesis for the major brain divisions in which these nuclei reside.

These results complement and extend previous reports of developmental changes in neuron number within song related nuclei in the zebra finch. The late neurogenesis found for $\mathrm{HVc}$ in the present data is a likely source for the substantial increase in the number of neurons in HVc of male zebra finches that occurs between days 25 and 53 (Bottjer et al., 1986). Also, it is known that giving E2 to 20 -d-old female zebra finches results in an increase over untreated females in the number of neurons in $\mathrm{HVC}_{\mathrm{c}}$ in adulthood (Nordeen et al., 1987). This increase could result from augmented incorporation into $\mathrm{HVc}$ of the neurons being produced at the time of the hormone treatment.

The present study detected very few labeled neurons in RA of animals that received ${ }^{3} \mathrm{H}$-thymidine injections after day 6 . This is consistent with reports that the number of neurons in this nucleus in males approaches adult values by day 12 after hatching and changes little thereafter (Konishi and Akutagawa, 1985; Bottjer et al., 1986). This also may indicate that many of the cells present in RA at $60 \mathrm{~d}$ were generated prior to hatching, before the earliest ${ }^{3} \mathrm{H}$-thymidine injections used in the present study. RA first receives afferents from HVc between days 3035 after hatching (Konishi and Akutagawa, 1985). These findings suggest a surprisingly long delay between RA neurogenesis and the arrival of a major input to this nucleus.

\section{Sex differences in the number of labeled neurons}

Following injections of ${ }^{3} \mathrm{H}$-thymidine in the first $30 \mathrm{~d}$ after hatching and examination at $60 \mathrm{~d}$, more labeled neurons were found in HVc and RA of males than in females. In HVc, sex differences in the number of labeled neurons were found in animals that had received the ${ }^{3} \mathrm{H}$-thymidine at any time in the first month. In RA, sex differences were most pronounced following ${ }^{3} \mathrm{H}$-thymidine injections covering the first week after hatching. Thymidine injections made at later ages labeled few RA neurons in either sex, but in these animals as well, males had higher numbers of labeled cells than females.

The frequency of labeled cells in dorsolateral LPO (the brain region that includes Area $X$ in males) did not differ between the sexes. This result is surprising when the extreme sexual dimorphism of Area $\mathrm{X}$ in adult zebra finches is considered and suggests that the generation of neurons during the first $30 \mathrm{~d}$ after hatching and their survival until $60 \mathrm{~d}$ are not major factors in the establishment of the pronounced sexual dimorphism in this brain area.

\section{Cell death in $H V C, R A$, and Area $X$}

In the sccond cxpcriment, dircet counts of pyknotic, degenerating cells in $\mathrm{HVC}_{\mathrm{C}}$ and $\mathrm{RA}$ revealed that female zebra finches have higher rates of cell death than males at specific ages during development. Comparisons between Area X in males and the geometrically analogous region in females revealed small but significantly higher cell death ratios in females in this region as well. Other researchers have suggested that cell death is a component in the process of sexual differentiation of vocal control regions, based principally on developmental changes in neuron number (Konishi and Akutagawa, 1985; Nordeen et al., 1987; Nordeen and Nordeen, 1988b). The present results provide direct evidence that this is true.

Estimates of neuron number in HVc and RA during development reported here are in general agreement with values reported in studies in which fewer ages were sampled (Konishi and Akutagawa, 1985; Bottjer et al., 1986; Nordeen and Nordeen, 1988b). Neuron number in HVc does not differ between the sexes on days 10 and 15 . However, HVc cell numbers diverge between the sexes at subsequent ages, increasing in males and decreasing in females. Neuron number in RA diverges between males and females 5-10 d later than it does in HVc. The divergence occurs because the number of neurons in RA of males remains essentially constant from day 20 to day 60 , while the number of neurons in RA of females drops substantially over this interval. Thus, there is an initial interval when the number of neurons in HVc and RA is increasing in both sexes. In females, this is followed by an interval when the number of neurons in $\mathrm{HVc}$ and $\mathrm{RA}$ is decreasing.

The timing of major changes in the number of neurons in $\mathrm{HVc}$ is in very good agreement with the pattern observed in cell death (whether measured as a simple count or as a ratio) when superimposed on relatively high levels of neurogenesis. The 
constant, almost linear, increase in the number of neurons in $\mathrm{HVc}$ of males is accompanied by relatively small fluctuations in cell death. The decrease in the number of neurons in $\mathrm{HVc}$ of females is accompanied by elevated numbers of pyknotic cells and by higher degenerating cell ratios.

At slightly older ages, similar associations are observed in RA. The number of neurons in RA levels off in males at 15$20 \mathrm{~d}$ of age; these are also the ages at which there is a peak in the number of pyknotic cells found in RA and in the cell death ratio. Furthermore, the divergence between the sexes in the number of neurons in RA occurs over the same ages as a large sex difference in pyknotic cell counts and ratios. The relative timings in HVc and RA of changes in neuron number and in cell death are similar. Thus, males and females diverge in the number of neurons in RA after they have diverged in the number of neurons in HVc. In females, the 2 indices of cell death are elevated in HVc earlier than in RA.

Pyknotic cell ratios were measured in males and females in dorsolateral LPO (DL-LPO), an area that encompasses Area X in males. In this region, cell death ratios are significantly higher in females than in males from day 15 to day 30 . Since pyknotic cell ratios in DL-LPO of males precisely map out both the time course and relative magnitude of death in Area $X$, it is likely that augmented death in DL-LPO of females represents the death of cells that in males would contribute to Area X. Furthermore, the absence of a sex difference in cell death for M-LPO (the region between DL-LPO and the ventricular site of proliferation for Area $\mathrm{X}$ ) strongly suggests that dimorphisms in $\mathrm{X}$ do not come about by selective loss during migration.

\section{Are hormone effects on song system structures direct or indirect?}

Sex differences in circulating steroids in young zebra finches (Hutchison et al., 1984) could affect the development of dimorphisms in song control nuclei in several ways. Hormones could promote neuron survival or differentiation either by interacting directly with steroid-sensitive neurons in HVc, RA, and Area $\mathrm{X}$ or by acting directly only on one brain region within this interconnected group of nuclei. A direct influence on one nucleus then might lead to increases in afferent or efferent synaptic capacity, which, in turn, could cause indirect, "cascading" effects on cell survival or elaboration in the other nuclei (discussed by Arnold and Gorski, 1984).

HVc may be a primary, direct site of action for steroids during the development of the song system (Bottjer et al., 1985). In turn, the consequences of hormonal effects in $\mathrm{HVc}$ might be transmitted to neurons in RA and Area X by virtue of HVc's projections to these 2 nuclei. Several lines of evidence support this argument. In male zebra finches, growth in HVc precedes that in RA (Bottjer et al., 1985), making a sequential effect possible. In adult males, HVc contains a larger proportion of steroid-binding cells than does RA. Area X, in contrast, has few if any steroid concentrating cells (Arnold et al., 1976; Arnold, 1980; Gahr et al., 1987; Walters et al., 1988). These results make it plausible that $\mathrm{HVC}_{\mathrm{c}}$ is more sensitive to steroids than RA or Area X. Moreover, a large percentage of the cells in $\mathrm{HVC}$ that bind androgens project to either RA or Area X (Sohrabji et al., 1987). Thus, by virtue of steroid binding characteristics, patterns of connectivity, and the timing of growth, HVc is well suited to exert trophic influences in RA and Area X.

Results from the present experiment are also consistent with the argument that $\mathrm{HVc}$ plays a pivotal role in the sexual dif- ferentiation of the song control system. In females, reductions in neuron number and increases in cell death occur earlier in $\mathrm{HVc}$ than in RA, suggesting that augmented cell death in $\mathrm{HVc}$ might result in a subsequent increase in RA cell death. In males, the first appearance of Area X occurs after the appearance of $\mathrm{HVc}$, making it possible that HVc influences the development of this nucleus as well.

Other evidence may also support the argument that hormonal effects on the sexual differentiation of some song control regions are mediated in part by $\mathrm{HVc}$. In other developing systems, cell survival is regulated by afferents (Okado and Oppenheim, 1984; Clarke, 1985; Furber et al., 1987; Linden and Piñon, 1987). Konishi and Akutagawa (1985) have reported that HVc afferents fail to innervate RA in female zebra finches during development. Thus, the sexual differentiation of RA in females may represent a natural case of "deafferentiation." Interestingly, comparisons of the time course and amount of RA cell death in males and females in the present experiment indicate that the female cell death rate is not only higher than in males, but that the highest level of cell death is delayed relative to the highest level of cell death in males (see Fig. 7). This pattern is also seen with experimental deafferentiation (Okado and Oppenheim, 1984). These results are consistent with a model in which cell survival in RA is an indirect consequence of steroid effects in $\mathrm{HV}_{\mathrm{c}}$.

The potential role of $\mathrm{HVc}$ in the differentiation of other song nuclei would be clarified if the time course of cell loss was known for specific subpopulations of neurons within this nucleus. $\mathrm{HVc}$ projections to Area $\mathrm{X}$ and RA derive from 2 distinct cell populations (Paton et al., 1985; Alvarez-Buylla et al., 1988; Nordeen and Nordeen, 1988a), and the present experiment cannot dissociate the time course of loss for these 2 cell classes. The cells that project to Area $\mathrm{X}$ tend to be formed before those that project to RA (Nordeen and Nordeen, 1988a). It may be that the time of peak cell death for these 2 cell groups also differs. Confirmation that elaboration or death occurs in the RA-projecting neuronal population in $\mathrm{HVc}$ before death or regression in the target cells in RA would be further support for a determinative role for $\mathrm{HVC}_{\mathrm{C}}$ in the differentiation of $\mathrm{RA}$.

\section{What processes initiate divergence between the sexes?}

An apparent paradox in the development of sex differences in the song system arises from the observations that the onset of sex differences in circulating estrogen occurs well before the divergence of RA volume (Hutchison et al., 1984; Konishi and Akutagawa, 1985) and cell death. It is clear that the song system is capable of responding to these early differences in steroid levels: gonadal steroids given to female zebra finches as early as the first days after hatching result in large increases in the number of neurons found in RA in adults (Gurney, 1981). Several observations suggest that a major determining factor in the timing of hormone effects on neuron survival may be the age at which vocal control areas establish interconnections. In the majority of developing neural systems that have been studied, cell death has been shown to occur specifically during intervals when extrinsic neuronal connections are first being established (reviewed by Oppenheim, 1981a; Cowan et al., 1984; see also Nordeen et al., 1985, and Sengelaub and Arnold, 1986, for results in a dimorphic spinal cord nucleus). If the development of the vocal control system follows the same pattern, the onset of sex differences in cell death would also be expected to occur at intervals during which regional connections are being made, a process that, at least in terms of RA and HVc, occurs several 
weeks after the onset of the critical period of hormonal sensitivity. Thus, although neurons in vocal control nuclei may be sensitive to circulating steroids early in development, the consequences of that sensitivity in terms of survival or death may not be manifested until a later developmental stage, when the neurons begin to interact with their afferent and/or efferent targets.

The present data provide indirect evidence suggesting that neuron specification is involved in the sexual differentiation of Area X. While cell death is slightly higher in females than in males, this may play only a minor role in the development of sex differences in Area $\mathrm{X}$. The size of the sex difference in pyknotic cell number is much smaller than in HVc or RA. Peak cell death ratios in this area are considerably lower than peak values for HVc and RA. In the present data, no significant sex differences in the frequency of ${ }^{3} \mathrm{H}$-labeled cells are found in DLLPO. A moderate difference in ${ }^{3} \mathrm{H}$-thymidine labeling has been reported in a similar study (Nordeen and Nordeen, 1988b). Together, these findings suggest that the net effects of genesis and death after hatching are much smaller than in HVc or RA and seem insufficient to account for the pronounced dimorphism of Area X. Analyses of cell death in medial LPO also fail to reveal sex differences, making it unlikely that neurons destined for Area X die preferentially in females while migrating from the ventricular zone.

Although Area X can be observed in males but not in females, neuron density in dorsolateral LPO is only $17 \%$ greater in males than in females at $60 \mathrm{~d}$ after hatching. Perhaps differential expression of factors such as the amount or quality of innervation from $\mathrm{HVc}$ or other areas results in the specification of a visually discrete, large Area $X$ in males and the apparent absence of this nucleus in females. For example, Lewis et al. (1981) describe a catecholaminergic input to DL-LPO in adult zebra finches. In males, this projection is most dense within Area X. In females, this projection is diffuse throughout DL-LPO, suggesting that connectivity patterns for this region differ in males and females. The sexual differentiation of Area $\mathrm{X}$ may involve the differential utilization of neurons that are similar in number and location in males and females. HVc afferents may be involved in the differentiation of Area X (Herrman and Arnold, 1988); if HVc input is responsible for the specification of a circumscribed nucleus, this scenario would require that $\mathrm{HVc}$ project to Area $\mathrm{X}$ by the time when the latter is first evident in males.

\section{Interactions between neurogenesis and cell death}

In the present experiments, scx differences were observed both in cell death and in the number of neurons incorporated into $\mathrm{HVc}$ and RA. The simplest interpretation of the present findings is that differential death of neurons is the major mechanism for the development of sex differences. The apparent sex difference in neurogenesis is most easily explained as the result of differential death of labeled cells during the interval between ${ }^{3} \mathrm{H}$ thymidine administration and sacrifice. In $\mathrm{HVc}$, continuous neurogenesis overlapping with moderate rates of cell death in males leads to the formation of a large nucleus. Females differ from males in that their rate of cell death is substantially higher, eliminating many of the neurons formed after hatching and resulting in a smaller nucleus. A similar process appears to occur in RA. Here, it is likely that the neuronal population is created before or shortly after hatching and is not substantially augmented later. The result is the same: moderate death resulting in a large structure in males and much higher death leaving a smaller structure in females. We do not know whether differential cell death completely accounts for dimorphic cell number; further experiments will be needed to determine whether differential neurogenesis occurs in the song system and could contribute to sexual differentiation.

The results underscore the need for direct measurement of cell death. Simple counts of the number of neurons in HVc and RA might suggest that cell death does not occur in these nuclei in males. The present data indicate that this conclusion would be incorrect. Cell loss in males appears to be offset by simultaneous neuron addition. Not only does cell death play a role in the development of these nuclei in males as well as females, but the process continues into the second month after hatching. In $\mathrm{HVc}$ especially, direct measurement of cell death indicates that major changes in the composition of the nucleus continue at ages when song is being acquired and perfected.

\section{Possible structure/function relations in development}

The present results indicate developmental changes in anatomy overlapping with song acquisition in males. Male zebra finches begin to produce crude vocal facsimilies of songs they are hearing from conspecific adults at approximately $25 \mathrm{~d}$ of age. By about $60 \mathrm{~d}$ of age, vocal output has become stereotyped and closely approximates stable adult song (Immelmann, 1969; Arnold, 1975; Eales, 1985). HVc neurogenesis occurs throughout the first $30 \mathrm{~d}$ after hatching. Between days 25 and 60 , an interval spanning much of song development, HVc neuron number in males increases by about $70 \%$. HVc has been shown to be part of a neural circuit involved in the storage and/or transfer of acquired sensorimotor information associated with song (McCasland and Konishi, 1981; Margoliash, 1983, 1986). Although the functions of ongoing neuron addition to $\mathrm{HVc}$ remain unknown, it is now clear that any neuronal model of song learning must account for large-scale continuing incorporation of new neurons into preexisting circuits.

Regressive events in brain development may serve important functions in the development of brain function and behavior (Oppenheim, 1981b; Finlay and Slattery, 1983; Cowan et al., 1984; Purves and Lichtman, 1985). Initial "overproduction" of neurons and synapses is followed by selective loss of cells and circuits, and by the strengthening of remaining neural connections in a manner appropriate for adult function. It is possible that the early death of neurons in brain areas that control singing is necessary for these areas to function appropriately. This process could be used to sculpt out the appropriate circuitry for song in males. Moreover, in zebra finches, this process is used differentially in the 2 sexes to create large dimorphisms. It may be that the timing or duration of these regressive events is susceptible to selective pressure (Katz, 1982; Ebbesson, 1984; Finlay et al., 1987). Thus, cell death could be a proximal mechanism whereby the degree of dimorphism in the song system across species is varied and thereby the degree of dimorphism in behavior as well (Brenowitz et al., 1985; Arnold et al., 1986).

Marler and Peters (1982) noted that the acquisition of song is also characterized by selective growth and regression. In the case of song development, young males form an elaborate repertoire of sounds and phrases from which "inappropriate" sounds are gradually deleted. This process results in a relative increase in the representation of other sounds more closely approximating adult song. Presently, the similarities between structural and functional change are intriguing parallels. As the timing of 
neural and bchavioral devclopment is more closely studied, and as the contributions to the song system of such precisely defined components as neurogenesis and neuronal death are more completely measured, it may become possible to determine the structural causes of these behavioral changes.

\section{References}

Abercrombie, M. (1946) Estimation of nuclear populations from microtome sections. Anat. Rec. 94: 239-247.

Alvarez-Buylla, A., M. Theelen, and F. Nottebohm (1988) Birth of projection neurons in the higher vocal center of the canary forebrain before, during, and after song learning. Proc. Natl. Acad. Sci. USA $85: 8722-8726$

Arnold, A. P. (1975) The effects of castration on song development in zebra finches. J. Exp. Zool. 191: 261-278.

Arnold, A. P. (1980) Quantitative analysis of sex differences in hormone accumulation in the zebra finch brain: Methodological and theoretical issues. J. Comp. Neurol. 189: 421-436.

Arnold, A. P., and S. M. Breedlove (1985) Organizational and activational effects of sex steroids on brain and behavior: A reanalysis. Horm. Behav. 19: 469-498.

Arnold, A. P., and R. A. Gorski (1984) Gonadal steroid induction of structural sex differences in the central nervous system. Annu. Rev. Neurosci. 7: 413-442.

Arnold, A. P., F. Nottebohm, and D. W. Pfaff (1976) Hormone concentrating cells in vocal control and other areas of the brain of the zebra finch. J. Comp. Neurol. 165: 478-512.

Arnold, A. P., S. W. Bottjer, E. A. Brenowitz, E. J. Nordeen, and K. W. Nordeen (1986) Sexual dimorphisms in the neural vocal control system in song birds: ontogeny and phylogeny. Brain Behav. Evol. 28: 22-31.

Bottjer, S. W., S. L. Glaessner, and A. P. Arnold (1985) Ontogeny of brain nuclei controlling song learning and behavior in zebra finches. J. Neurosci. 5: 1556-1562.

Bottjer, S. W., E. Meisner, and A. P. Arnold (1986) Changes in neuronal number, density and size account for increases in volume of song-control nuclei during song development in zebra finches. Neurosci. Lett. $67:$ 263-268.

Brenowitz, E. A., A. P. Arnold, and R. N. Levin (1985) Neural correlates of female song in a tropical duetting species. Brain Res. 343: 104-112.

Burd, G. D., J. A. Paton, and F. Nottebohm (1985) Separate classes of interneurons in a song nucleus: Those showing GABA immunoreactivity and those born in adulthood. Soc. Neurosci. Abstr. 11:964.

Chu-Wang, D.-W., and R. W. Oppenheim (1978) Cell death of motoneurons in the chick embryo spinal cord. I. A light and electron microscopic study of naturally occurring and induced cell loss during development. J. Comp. Neurol. 177: 33-58.

Clarke, P. G. H. (1985) Neuronal death during development in the isthmo-optic nucleus of the chick: Sustaining role of afferents from the tectum. J. Comp. Neurol. 234: 365-379.

Cowan, M. W., J. W. Fawcett, D. D. M. O'Leary, and B. B. Stanford (1984) Regressive events in neurogenesis. Science 225: 1258-1265.

DeVoogd, T. J. (1986) Steroid interactions with structure and function of avian song control regions. J. Neurobiol. 17: 177-201.

DeVoogd, T. J., H. Norden, and C. Gould (1986) Dendritic retraction and spine elimination in females contribute to sex dimorphisms in the avian song system. Soc. Neurosci. Abstr. 12: 1214.

Eales, L. A. (1985) Song learning in zebra finches: Some effects of song model availability on what is learnt and when. Anim. Behav. 33: 1293-1300.

Ebbesson, S. O. E. (1984) Evolution and ontogeny of neural circuits. Behav. Brain Sci. 7: 321-331.

Finlay, B. L., and M. Slattery (1983) Local differences in amount of early death in neocortex predict adult local specializations. Science 219: 1349-1351.

Finlay, B. L., D. R. Sengelaub, and C. A. Berian (1986) Control of cell number in the developing visual system. 1. Effects of monocular enucleation. Dev. Brain Res. 28: 1-10.

Finlay, B. L., K. C. Wikler, and D. R. Sengelaub (1987) Regressive events in brain development and scenarios for vertebrate brain evolution. Brain Behav. Evol. 30: 102-117.
Furber, S., R. W. Oppenheim, and D. Prevettc (1987) Naturally occurring neuron death in the ciliary ganglion of the chick embryo following removal of preganglionic input: Evidence for the role of afferents in ganglion cell survival. J. Neurosci. 7: 1816-1832.

Gahr, M., G. Flügge, and H.-R. Güttinger (1987) Immunocytochemical localization of estrogen-binding neurons in the songbird brain. Brain Res. 402: 173-177.

Goldman, S., and F. Nottebohm (1983) Neuronal production, migration and differentiation in a vocal control nucleus of the adult female canary brain. Proc. Natl. Acad. Sci. USA 80: 2390-2394.

Gurney, M. (1981) Hormonal control of cell form and number in the zebra finch song system. J. Neurosci. 1: 658-673.

Gurney, M. (1982) Behavioral correlates of sexual differentiation in the zebra finch song system. Brain Res. 231 : 153-172.

Herrmann, K., and A. P. Arnold (1988) Effect of HVc lesions on estradiol-induced masculinization of zebra finch song system. Soc. Neurosci. Abstr. 14: 284.

Hutchison, J. B., J. C. Wingfield, and R. E. Hutchison (1984) Sex differences in plasma concentrations of steroids during the sensitive period for brain differentiation in the zebra finch. J. Endocrinol. 103: 363-369.

Immelmann, K. (1969) Song development in the zebra finch and other estrildid finches. In Bird Vocalizations, R. A. Hinde, ed., pp. 61-74, Cambridge U. P., Cambridge.

Katz, M. J. (1982) Ontogenetic mechanisms: The middle ground of evolution. In Evolution and Development, J. T. Bonner, ed., pp. 207211 , Springer-Verlag, New York.

Kelley, D. B. (1988) Sexually dimorphic behaviors. Annu. Rev. Neurosci. 11: 225-251.

Konishi, M. (1985) Birdsong: From behavior to neuron. Annu. Rev. Neurosci. 8: 125-170.

Konishi, M., and E. Akutagawa (1985) Neuronal growth, atrophy and death in a sexually dimorphic song nucleus in the zebra finch brain. Nature 315: 145-147.

Lewis, J. W., S. M. Ryan, A. P. Arnold, and L. L. Butcher (1981) Evidence for catecholamine projection to Area $\mathrm{X}$ in the zebra finch. J. Comp. Neurol. 196: 347-354.

Linden, R., and L. G. P. Piñon (1987) Dual control by targets and afferents of developmental neuronal death in the mammalian central nervous system: A study in the parabigeminal nucleus of the rat. $\mathbf{J}$. Comp. Neurol. 266: 141-149.

Margoliash, D. (1983) Acoustic parameters underlying the responses of song-spccific ncurons in the white-crowned sparrow. J. Neurosci. 3: $1039-1057$.

Margoliash, D. (1986) Preferences for autogenous song by auditory neurons in a song system nucleus of the white crowned sparrow. $J$. Neurosci. 6: 1643-1661.

Marler, P., and S. Peters (1982) Developmental overproduction and selective attrition: New processes in the epigenesis of birdsong. Dev. Psychobiol. 15: 369-378.

McCasland, J. S., and M. Konishi (1981) Interaction between auditory and motor activities in an avian song control nucleus. Proc. Natl. Acad. Sci. USA 78: 7815-7819.

Nixdorf, B. E., S. Davis, and T. J. DeVoogd (1988) Neuronal types in a song control nucleus of the canary brain: A quantitative computerized Golgi study. J. Comp. Neurol. (in press).

Nordeen, E. J., and Nordeen, K. W. (1988b) Sex and regional differences in the incorporation of neurons born during song learning in zebra finches. J. Neurosci. 8: 2869-2874.

Nordeen, E. J., K. W. Nordeen, D. R. Sengelaub, and A. P. Arnold (1985) Androgens prevent normally occurring cell death in a sexually dimorphic spinal nucleus. Science 229: 671-673.

Nordeen, E. J., K. W. Nordeen, and A. P. Arnold (1987) Sexual differentiation of androgen accumulation within the zebra finch brain through selective cell loss and addition. J. Comp. Neurol. 259: 393399.

Nordeen, K. W., and E. J. Nordeen (1988a) Projection neurons within a vocal motor pathway are born during song learning in zebra finches. Nature 334: 149-151.

Nottebohm, F. (1985) Neuronal replacement in adulthood. Ann. NY Acad. Sci. 457: 143-161.

Nottebohm, F., and A. P. Amold (1976) Sexual dimorphism in vocal control areas of the song bird brain. Science 194: 211-213.

Nottebohm, F.; T. M. Stokes, and C. M. Leonard (1976) Central control of song in the canary. J. Comp. Neurol. 165: 457-468. 
Okado, N., and R. W. Oppenheim (1984) Cell death of motorneurons in the chick embryo spinal cord. IX. The loss of motorneurons following removal of afferent inputs. J. Neurosci. 4: 1639-1652.

Oppenheim, R. W. (1981a) Neuronal cell death and some related regressive phenomena during neurogenesis: A selective historical review and progress report. In Studies in Developmental Neurobiology; Essays in Honor of Victor Hamburger, W. M. Cowan, ed., pp. 74133, Oxford U. P., New York.

Oppenheim, R. W. (1981b) Ontogenetic adaptations and retrogressive processes in the development of the nervous system and behavior. In Maturation and Development, $\mathrm{K}$. Connolly and $\mathrm{H}$. Prechtel, eds., Lippincott, Philadelphia.

Paton, J. A., and F. Nottebohm (1984) Neurons generated in the adult brain are recruited into functional circuits. Science 225 : 1046-1048.

Paton, J. A., B. E. O'Loughlin, and F. Nottebohm (1985) Cells born in adult canary forebrain are local interneurons. J. Neurosci. $5: 3088-$ 3093.

Pohl-Apel, G., and R. Sossinka (1984) Hormonal determination of song capacity in females of the zebra finch: Critical phase of treatment. Z. Tierpsychol. 64: 330-336.

Price, P. H. (1979) Developmental determinants of structure in zebra finch song. J. Comp. Physiol. Psychol. 93: 260-277.

Purves, D., and J. W. Lichtman (1985) Principles of Neural Development, Sinauer, Sunderland, MA.
Ryan, S. M., and A. P. Arnold (1981) Evidence for cholinergic participation in the control of bird song: Acetylcholinesterase distribution and muscarinic receptor autoradiography in the zebra finch brain. J. Comp. Neurol. 202: 211-219.

Sengelaub, D. R., and A. P. Arnold (1986) Development and loss of early projections in a sexually dimorphic rat spinal nucleus. $\mathrm{J}$. Neurosci. 6: 1613-1620.

Sohrabji, F., K. W. Nordeen, and E. J. Nordeen (1989) Projections of androgen-accumulating neurons in a nucleus controlling avian song. Brain Res. 488: 253-259.

Tsai, H. M., B. B. Garber, and L. M. H. Larramendi (1981a) ${ }^{3} \mathrm{H}-$ Thymidine autoradiographic analysis of telencephalic histogenesis in the chick embryo: 1. Neuronal birthdates of telencephalic compartments in situ. J. Comp. Neurol. 198: 275-292.

Tsai, H. M., B. B. Garber, and L. M. H. Larramendi (1981b) ${ }^{3} \mathrm{H}$ Thymidine auto-radiographic analysis of telencephalic histogenesis in the chick embryo. 2. Dynamics of neuronal migration, displacement and aggregation. J. Comp. Neurol. 198: 293-306.

Walters, M. J., B. S. McEwen, and C. F. Harding (1988) Estrogen receptor levels in hypothalamic and vocal control nuclei in the male zebra finch. Brain Res. 459: 37-43.

Wong, R. O. L., and A. Hughes (1987) Role of cell death in the topogenesis of neuronal distributions in the developing cat retinal ganglion cell layer. J. Comp. Neurol. 262: 496-511. 